\title{
Cytotoxic effects of intra and extracellular zinc chelation on human breast cancer cells
}

\author{
Mohammad Hashemi $^{\mathrm{a}, *, 1}{ }^{\text {, Saeid Ghavami }}{ }^{\mathrm{a}, \mathrm{b}}$, Mehdi Eshraghi ${ }^{\mathrm{b}}$, Evan P. Booy ${ }^{\mathrm{b}}$, Marek Los ${ }^{\mathrm{b}, \mathrm{c}, *, 1}$ \\ ${ }^{a}$ Department of Clinical Biochemistry, School of Medicine, Zahedan University of Medical Sciences, Zahedan, Iran \\ ${ }^{\mathrm{b}}$ Manitoba Institute of Cell Biology, and Department of Biochemistry and Medical Genetics, Univ. Manitoba, Winnipeg, Canada \\ ${ }^{\mathrm{c}}$ Department of Human Anatomy and Cell Science, Univ. Manitoba, Winnipeg, Canada
}

Received 4 January 2006; received in revised form 2 November 2006; accepted 6 November 2006

Available online 10 November 2006

\begin{abstract}
Zinc is an essential trace element with cofactor functions in a large number of proteins of intermediary metabolism, hormone secretion pathways, immune defence mechanisms, and as a cofactor of transcription factors it is also involved in the control of gene expression. Our study demonstrates that the modulation of intra and extracellular zinc alone is sufficient to induce metabolic changes or even apoptosis in two model human breast cancer cell lines MCF-7 and MDA-MB468. Treatment of breast cancer cells with different concentrations of a cell membrane permeable zinc chelator, $N, N, N^{\prime}, N^{\prime}$-tetrakis(2-pyridylmethyl)ethylenediamine (TPEN) and the membrane impermeable zinc chelator, diethylenetriaminepentacetic acid, (DTPA) resulted in a significant increase of cell death. Features of apoptosis, such as chromatin condensation and nuclear fragmentation accompanied the DTPA and TPEN-induced cell death. A significant increase in the activity of caspase-9 was observed in both cell lines; whereas, caspase-3 activity was only increased in MDA-MB468 cells since caspase-3 is not expressed in MCF-7 cells. Caspase8 activation was negligible in both cell lines. Addition of $\mathrm{Zn}^{2+}$ or $\mathrm{Cu}^{2+}$ prevented DTPA and TPEN-induced cytotoxicity, indicating that both bivalent cations can be replaced functionally to a certain extent in our experimental system. Interestingly, addition of $\mathrm{Ca}^{2+}$, or $\mathrm{Mg}^{2+}$ had no effect. The antioxidant $\mathrm{N}$-Acetyl-L-Cysteine inhibited the cytotoxic effect of DTPA and TPEN, indicating that oxidative stress is the likely mediator of Zn-deficiency-related cell death.
\end{abstract}

(C) 2006 Elsevier B.V. All rights reserved.

Keywords: Apoptosis; Breast cancer; Caspase; Cu/Zn-dismutase; Diethylenetriaminepentacetic acid; $N, N, N^{\prime}, N^{\prime}$-tetrakis(2-pyridylmethyl)ethylenediamine

\section{Introduction}

Cell death is essential for the homeostasis of multicellular organisms, as well as embryonic and post-embryonic development (Hashemi et al., 2005; Hashemi and Kroczak, 2005; Los et al., 1997, 1999). Zinc serves many essential functions in mammalian cells and is an important micronutrient involved in

\footnotetext{
* Corresponding authors. Los is to be contacted at Manitoba Institute of Cell Biology ON6010-675 McDermot Ave. University of Manitoba, Winnipeg, MB, Canada, R3E 0V9. Tel.: +1 2047872294 (office), 1403 (lab), 4108 (lab); fax: +1 204787 2190. Hashemi, Department of Clinical Biochemistry, School of Medicine, Zahedan University of Medical Sciences, Zahedan, I. R. Iran. Tel.: +98 917 3640366; fax: +98 5412427913.

E-mail addresses: mhd.hashemi@gmail.com, hashemim@zdmu.ac.ir (M. Hashemi), losmj@cc.umanitoba.ca (M. Los).

${ }^{1}$ Both authors share senior authorship.
}

structural and regulatory functions (Berg and Shi, 1996; Vallee and Falchuk, 1993). Zinc interacts with zinc-binding motifs, so called "zinc finger" domains, and thereby acts as a cofactor for several hundred enzymes (Heximer and Forsdyke, 1993; Klug, 1999; Prasad, 1991; Sukegawa and Blobel, 1993). Additionally, many transcription factors contain zinc fingers that facilitate interaction with DNA. Zinc ions also specifically bind to various membrane receptors, transporters, and channels, thereby modulating their activity (Huang, 1997). Hence, it is not very surprising that severe depletion of zinc has profound effects on cell physiology. Consistently, cellular zinc shortage induced by zinc-deficient medium or cell permeable zinc chelators, has been shown to result in cell dysfunction (Kennedy et al., 1994; Mares-Perlman et al., 1996; McClain et al., 1985; Prasad, 1985) as well as apoptosis induction in various cell types (Adler et al., 1999; Ahn et al., 1998; Martin 
et al., 1991; McCabe et al., 1993; Rudolf and Cervinka, 2004; Treves et al., 1994; Truong-Tran et al., 2000b; Zalewski et al., 1993).

The impaired regulation of physiological cell death signalling may contribute to malignant transformation. Furthermore, recent observations suggest that this process might occur or be enhanced in the presence of zinc ions, since they are able to suppress apoptosis by interfering with several molecular targets in numerous cell types (Fukamachi et al., 1998; Perry et al., 1997). We have previously shown that calprotectin (S100A8/ S100A9) and an extracellular $\mathrm{Zn}^{2+}$ ion chelator, DTPA, induced apoptotic death of colon cancer cell lines (Ghavami et al., 2004). Furthermore, several drugs have bivalent cation chelating activity (Behroozi et al., 1996; Bergan et al., 2001). Thus, the purpose of this work was to study the biological mechanisms and significance of the depletion of labile endogenous $\mathrm{Zn}^{2+}$ stores in the cell. One of the main problems in breast cancer treatment is the occurrence of estrogen receptor (ER) negative tumors that are resistant to anti-hormone therapy. To reveal possible ER-related differences in response to $\mathrm{Zn}$ depletion, two human breast cancer cell lines are used as a model, MCF-7 (ER ${ }^{+}$) and MDA-MB468 (ER $\left.{ }^{-}\right)$. In addition, caspase- 3 is not expressed in MCF-7 cell line; therefore, this study will clarify the role of caspase-3 in zinc ion depletioninduced cell death.

\section{Materials and methods}

\subsection{Materials and reagents}

TPEN ( $N, N, N^{\prime}, N^{\prime}$-tetrakis(2-pyridylmethyl)ethylenediamine), DTPA, Zinquin, culture media and related compounds were purchased from Sigma Co. (USA). Cell culture plastic ware was obtained from Nunc Co. (Denmark), caspase-3 and -8 colorimetric assay kits were from Sigma (Germany). Caspase-9 colorimetric assay kit (Cat. no. BF10100) was obtained from R\&D systems Co. (USA). Monoclonal mouse-anti-cytochrome $c$ antibody was from Santa Cruz Biotechnologies (USA).

\subsection{Cell culture}

MDA-MB468 and MCF-7 cells were incubated at $37^{\circ} \mathrm{C}$ in a humidified incubator with $5 \% \mathrm{CO}_{2}$ and $95 \%$ air.

\subsection{Cytotoxicity assay}

To evaluate the cytotoxic effect of DTPA and TPEN on the breast cancer cell lines; MTT (3-(4,5-dimethyl-2-thiazolyl)-2,5diphenyl-2H-tetrazolium bromide) colorimetric assay was applied (Ghavami et al., 2005a). Briefly, asynchronously growing cells $\left(1.5 \times 10^{4}\right.$ cells $\left./ \mathrm{ml}\right)$ were transferred into 96well culture plates and incubated for $24 \mathrm{~h}$. The culture medium was replaced by fresh medium containing different concentrations of DTPA and TPEN, and incubated for 24, 48 and $72 \mathrm{~h}$. Then, the MTT assay was performed and cell viability was calculated using the equation: (mean OD of treated cells/mean OD of control cells) $\times 100$.

\subsection{Measurement of apoptosis by flow cytometry}

Apoptosis was measured using the Nicoletti method (Barczyk et al., 2005; Maddika et al., 2005). Briefly, cells grown in 12 well plates were treated with DTPA $(0-100 \mu \mathrm{M})$, and TPEN $(0-20 \mu \mathrm{M})$ for the indicated time periods, after scraping, cells were harvested by centrifugation at $800 \mathrm{~g}, 4{ }^{\circ} \mathrm{C}$, for $5 \mathrm{~min}$. The cells were washed once with PBS, and then resuspended in a hypotonic PI lysis buffer (1\% sodium citrate, $0.1 \%$ Triton X-100, $0.5 \mathrm{mg} / \mathrm{ml}$ RNase A, $40 \mu \mathrm{g} / \mathrm{ml}$ propidium iodide). Cell nuclei were then incubated for $30 \mathrm{~min}$ at $30^{\circ} \mathrm{C}$ and the nuclei were subsequently analyzed by flow cytometry. Nuclei to the left of the G1 peak containing hypodiploid DNA were considered to be apoptotic.

\subsection{Analysis of cellular morphology}

Cellular morphology was assessed as previously described in our laboratory using Hoechst 33258 fluorescence staining (Ghavami et al., 2005a), and inverted microscope (Micros, Austria).

\subsection{Quantification of intracellular labile Zn (II) by Zinquin fluorescence}

Zinquin was used to estimate the intracellular zinc concentrations as described previously (Ghavami et al., 2004). Briefly, after treatment with TPEN or DTPA for $24 \mathrm{~h}, 10^{6}$ cells were incubated in PBS containing $1 \mathrm{mg} / \mathrm{ml}$ ovalbumin and $25 \mu \mathrm{M}$ Zinquin for $30 \mathrm{~min}$. After $30 \mathrm{~min}$ at room temperature, the cells were transferred into fluorimetry grade cuvettes, and the fluorescence was measured at excitation/emission wavelengths of 365/490 nm in a Shimadzu RF 5000 spectrofluorimeter.

\subsection{Mitochondrial transmembrane potential $\left(\Psi_{m}\right)$ analysis}

To measure the $\Psi_{\mathrm{m}}$ of our model cell lines, the fluorescent probe JC-1 (5,5,6,6-tetrachloro-1,1,3,3-tetraethylbenzimidazole carbocyanide iodide) was used. JC-1 exists as a monomer at low values of $\Psi_{\mathrm{m}}$ (green fluorescence), while it forms aggregates at high $\Psi_{\mathrm{m}}$ (red fluorescence). Thus, mitochondria with normal $\Psi_{\mathrm{m}}$ concentrate JC-1 into aggregates (red fluorescence), but with de-energized or depolarized mitochondria, JC-1 forms monomers (green fluorescence). Briefly, MCF-7 and MDAMB468 cells treated with different concentrations of DTPA and TPEN for $16 \mathrm{~h}\left(5 \times 10^{5}\right)$ were collected by scraping, washed in phosphate buffered saline (PBS; $\mathrm{pH}=7.4$ ), and incubated for $15 \mathrm{~min}$ at $37^{\circ} \mathrm{C}$ with $2.5 \mu \mathrm{g} / \mathrm{ml} \mathrm{JC}-1$. Cells were pelleted at $400 \mathrm{~g}$ for $5 \mathrm{~min}$ in room temperature, washed in PBS, and analyzed by flow cytometry using Coulter EPICS-XL (Coulter, Miami, FL, USA). The analyzer threshold was adjusted on the forward light scatter channel to exclude most of the sub-cellular debris. Photomultiplier settings were adjusted to detect JC-1 monomer fluorescence signals on the filter 1 (FL1) detector (green fluorescence, $530 \mathrm{~nm}$ ) and JC-1 aggregate fluorescence signals on the FL2 detector (red fluorescence, $590 \mathrm{~nm}$ ). Mean fluorescence intensity values for FL1 and FL2, expressed as 
relative linear fluorescence channels, were obtained for all experiments. In each experiment, at least 15,000 events were analyzed.

\subsection{Cell fractionation}

Cytoplasmic and mitochondrial fractions were separated by differential centrifugation (Barczyk et al., 2005; Maddika et al., 2005). Briefly, the cells were treated with DTPA (50 $\mu \mathrm{M})$ and TPEN $(10 \mu \mathrm{M})$, then harvested and washed once with PBS after
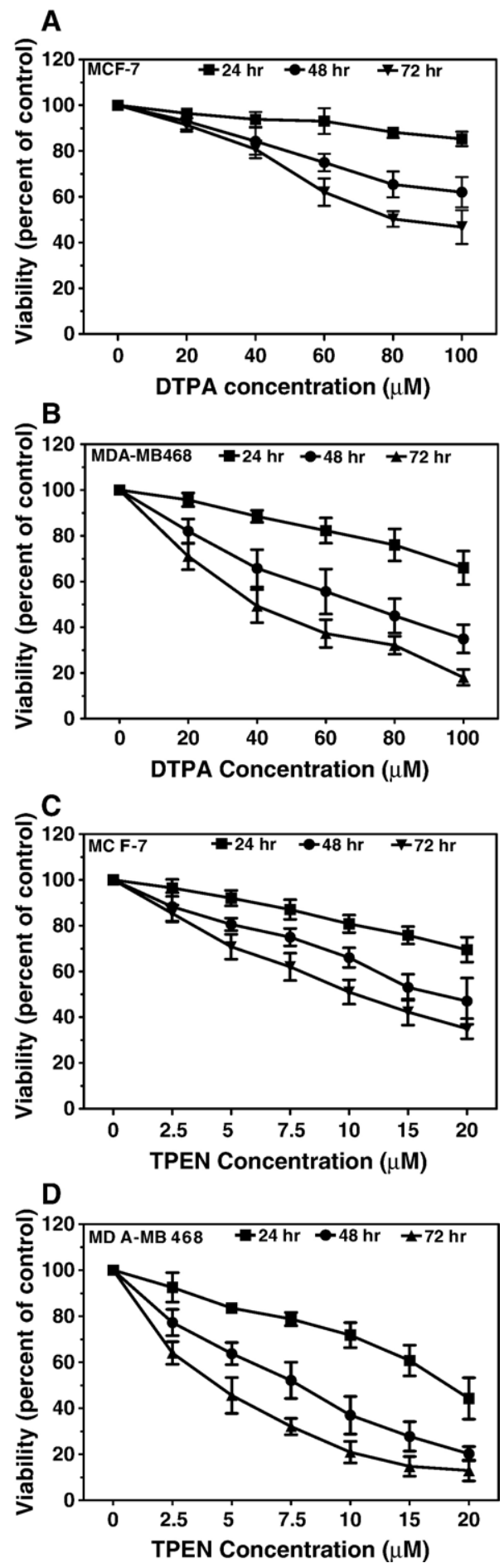

the indicated time points. The cells were resuspended for $5 \mathrm{~min}$ on ice in a lysis buffer: $10 \mathrm{mM}$ Tris- $\mathrm{HCl}(\mathrm{pH} 7.8), 1 \%$ Nonidet P-40, $10 \mathrm{mM}$ mercaptoethanol, $0.5 \mathrm{mM} \mathrm{PMSF,} 1 \mathrm{mg} / \mathrm{ml}$ aprotinin and $1 \mathrm{mg} / \mathrm{ml}$ leupeptin. In some experiments, an equal amount of distilled water was added to the cells in order to increase the cell lysis. Cells were then sheared by passing them through a 22-gauge needle. The nuclear fraction was recovered by centrifugation at $600 \mathrm{~g}$ for $5 \mathrm{~min}$, and the 'low-speed' supernatant was centrifuged at $10,000 \mathrm{~g}$ for $30 \mathrm{~min}$ to obtain the mitochondrial fraction (pellet) and the cytosolic fraction (supernatant). The mitochondrial fraction was further lysed in the buffer: $10 \mathrm{mM}$ Tris (pH 7.4), $150 \mathrm{mM} \mathrm{NaCl}, 1 \%$ Triton X100, 5 mM EDTA (pH 8.0).

\subsection{Immunoblotting}

The release of cytochrome $c$ was detected by immunoblotting. The cells were treated with DTPA $(50 \mu \mathrm{M})$ and TPEN $(10 \mu \mathrm{M})$ for the indicated time periods and the extracts were prepared as described above. Protein $(30 \mu \mathrm{g})$ was separated by denaturing SDS-PAGE and then transferred onto nylon membranes. The membranes were blocked in 5\% non-fat dried milk in TBS and then incubated overnight with the primary antibodies at $4{ }^{\circ} \mathrm{C}$. The blots were then incubated with the corresponding secondary antibodies conjugated with HRP at room temperature for $1 \mathrm{~h}$. Visualization was carried out by enhanced chemiluminescence (ECL) detection (AmershamPharmacia Biotech).

\subsection{Caspase-3, -8, and -9 activation assays}

Caspase-3 (using DEVD-pNA as substrate), caspase8 (using Ac-IETD-pNA as substrate) and caspase-9 (using LEHD-pNA as substrate) colorimetric assay kits were used to investigate the activity of these caspases in the treated MCF-7 and MDA-MB468 cells. Briefly, to estimate caspase- 3 and -8 activities, cells were lysed by incubation with cell lysis buffer on ice for $15 \mathrm{~min}$ and then centrifuged at $20,000 \mathrm{~g}$ for $10 \mathrm{~min}$ at $4{ }^{\circ} \mathrm{C}$. For caspase- 9 activation assay, cells were lysed by incubation with cell lysis buffer on ice for $10 \mathrm{~min}$ and then centrifuged at $10,000 \mathrm{~g}$ for $1 \mathrm{~min}$ at $4{ }^{\circ} \mathrm{C}$. Enzymatic reactions were carried out in a 96-well flat-bottom microplate. To each

Fig. 1. The toxic effect of DTPA (cell impermeable) and TPEN (cell permeable) zinc ion chelators on breast cancer cell lines. Effect of DTPA and TPEN on the growth of MCF-7 (A, C) and MDA-MB468 (B, D) breast cancer cell lines. The cells were treated with different concentrations of DTPA and TPEN for 24, 48 and $72 \mathrm{~h}$, and the viability was assessed by MTT assay. DTPA induced significant cytotoxic effect in MCF-7 (A) at concentration $\geq 80 \mu \mathrm{M}$ in $24 \mathrm{~h}$ $(P<0.05)$, this effect was observed at concentration $\geq 40 \mu \mathrm{M}(P<0.001)$ in 48 and $72 \mathrm{~h}$. In MDA-MB468 (B), DTPA induced significant cytotoxic effect at concentration $\geq 40 \mu \mathrm{M}$ in $24 \mathrm{~h}(P<0.01)$, this effect was observed at all concentrations $(P<0.001)$ in 48 and $72 \mathrm{~h}$. TPEN induced significant cytotoxic effect in MCF-7 (C) at concentration $\geq 7.5 \mu \mathrm{M}$ in $24 \mathrm{~h}(P<0.01), \geq 5 \mu \mathrm{M}$ in $48 \mathrm{~h}$ $(P<0.001)$ and all concentrations in $72 \mathrm{~h}$. In MDA-MB468 cells (D), TPEN induced significant cytotoxicity at concentration $\geq 5 \mu \mathrm{M}$ in $24 \mathrm{~h}(P<0.001)$ and in 24 and $48 \mathrm{~h}$, cytotoxicity was observed at all concentrations $(P<0.001)$. Results are expressed as percentage of corresponding control and represent the mean \pm S.D. of six repeats. 
reaction sample 5, 25, and $50 \mu 1$ of cell lysate (100-200 $\mu \mathrm{g}$ total protein) were added for caspase- $3,-8$, and -9 respectively. Additional controls, one free from cell lysate and the other lacking substrate as well as caspase- 3 and -8 positive controls were included. Protein content was estimated by Bradford method (Bradford, 1976). The activities were expressed as $\mathrm{nmol} / \mathrm{min} / \mathrm{mg}$ protein

\subsection{Effect of $N$-Acetyl-l-Cysteine on DTPA and TPEN cytotoxicity}

To study the involvement of reactive oxygen species in the induction of apoptosis, the cell lines were pre-treated with increasing concentrations of $\mathrm{N}$-Acetyl-1-cysteine for $24 \mathrm{~h}$. The cell lines were then treated with DTPA $(100 \mu \mathrm{M})$ and TPEN $(10 \mu \mathrm{M})$ for $48 \mathrm{~h}$.

\subsection{Effect of various bivalent metal ions on DTPA and TPEN cytotoxicity}

To evaluate the effect of different bivalent metal ions (calcium, magnesium, copper, zinc), the cell lines were treated with DTPA $(100 \mu \mathrm{M})$ or TPEN $(10 \mu \mathrm{M})$ for $48 \mathrm{~h}$ in the presence of increasing concentrations of metal ions as indicated. Cell viability was then assessed by the MTT-assay (Ghavami et al., 2005a).

\subsection{Statistical analysis}

The results were expressed as the mean \pm S.D. and statistical differences were evaluated by one-way analysis of variance between groups (ANOVA) followed by Tukey's post hoc test. Statistical analyses were performed using the software package SPSS version 11 . The $P<0.05$ was considered significant.

\section{Results}

\subsection{Both, intra and extracellular zinc chelators induce cell death}

To determine the effect of DTPA and TPEN on cell viability we have tested the effect of zinc depletion by the MTT assay. As it is shown in Fig. 1, treatment of MCF-7 and MDA-MB468 cells with DTPA and TPEN resulted in a significant amount of cell death that was both time and dose-dependent. However, both cell lines displayed a marked difference in their sensitivity toward both agents as far as time-course and effective doses are compared. The treatment of MCF-7 cells with the cell impermeable $\mathrm{Zn}$ chelator, DTPA, resulted in significantly reduced cell viability at concentrations higher than $40 \mu \mathrm{M}$ within 48 and $72 \mathrm{~h}$. At $24 \mathrm{~h}$, the cytotoxicity was not significant at any tested dose (Fig. 1A). In comparison, cells treated with DTPA showed significant cell death at concentrations higher than $60 \mu \mathrm{M}$ within $24 \mathrm{~h}$. At 48 and $72 \mathrm{~h}$, cytotoxicity was significant at a concentration higher than $20 \mu \mathrm{M}$ (Fig. 1B).

Treatment of MCF-7 cells with the cell permeable $\mathrm{Zn}$ chelator TPEN resulted in significant cell death at a concentration much lower than used for the cell-membrane-imperme-
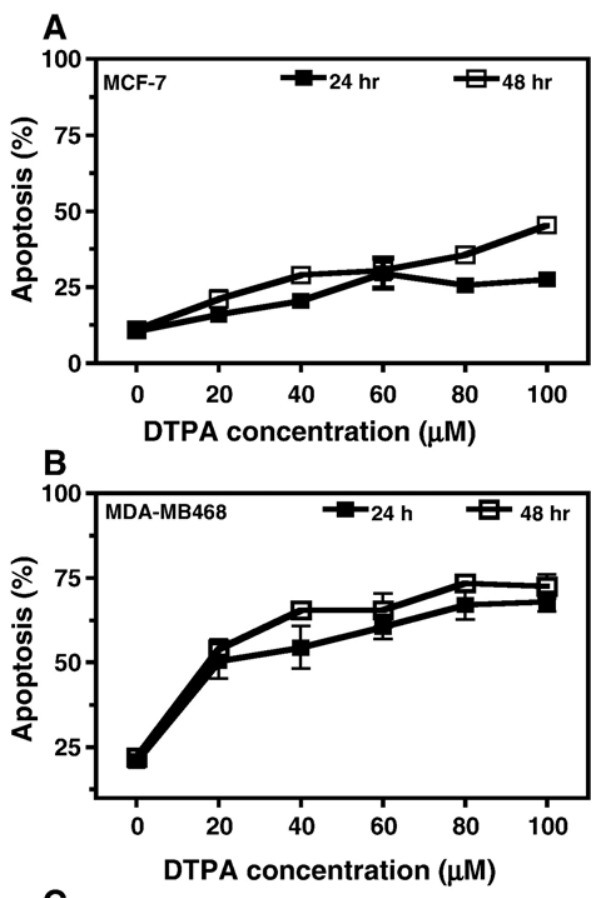

c
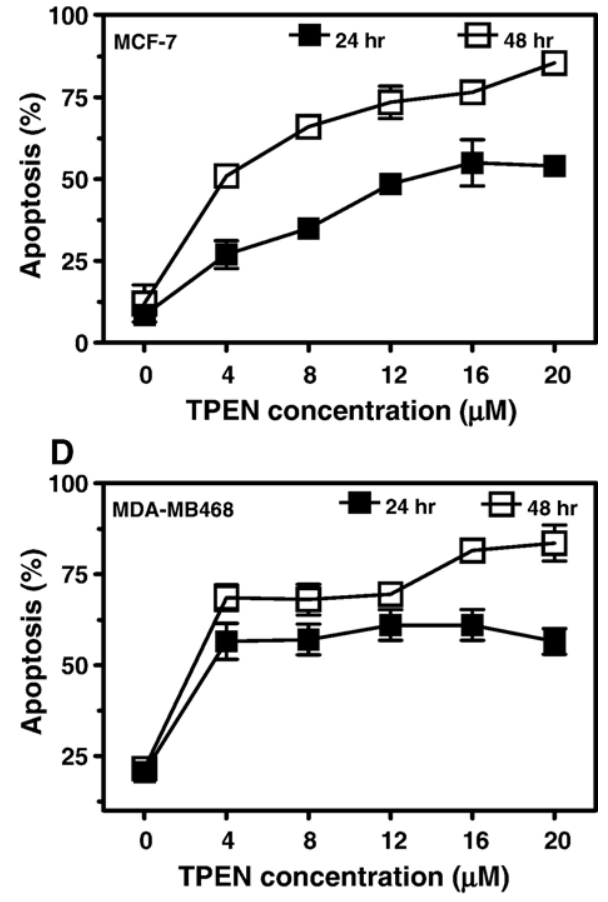

Fig. 2. Apoptotic cell death in MCF-7 and MDA-MB468 cells induced by extracellular (DTPA) and intracellular (TPEN) zinc ion chelators. The cells were treated with different concentration of DTPA (A, B) and TPEN (C, D) for $24 \mathrm{~h}$ and $48 \mathrm{~h}$. Apoptotic cell death was then detected by flow cytometry (Nicoletti method). DTPA induced significant apoptotic effect in MCF-7 (A) at concentration $\geq 40 \mu \mathrm{M}$ in $24 \mathrm{~h}(P<0.05)$ and significant apoptosis was observed at all concentrations in $48 \mathrm{~h}(P<0.001)$. DTPA induced significant apoptosis in MDA-MB468 (B) at al concentrations in all indicated times $(P<0.001)$. TPEN induced significant apoptotic effect in MCF-7 (C) $(P<0.01)$ and MDA-MB468 (D) $(P<0.001)$ at all concentrations in all indicated times. Results are expressed as percentage of apoptotic cells, and represent the mean \pm S.D. of four independent experiments. 


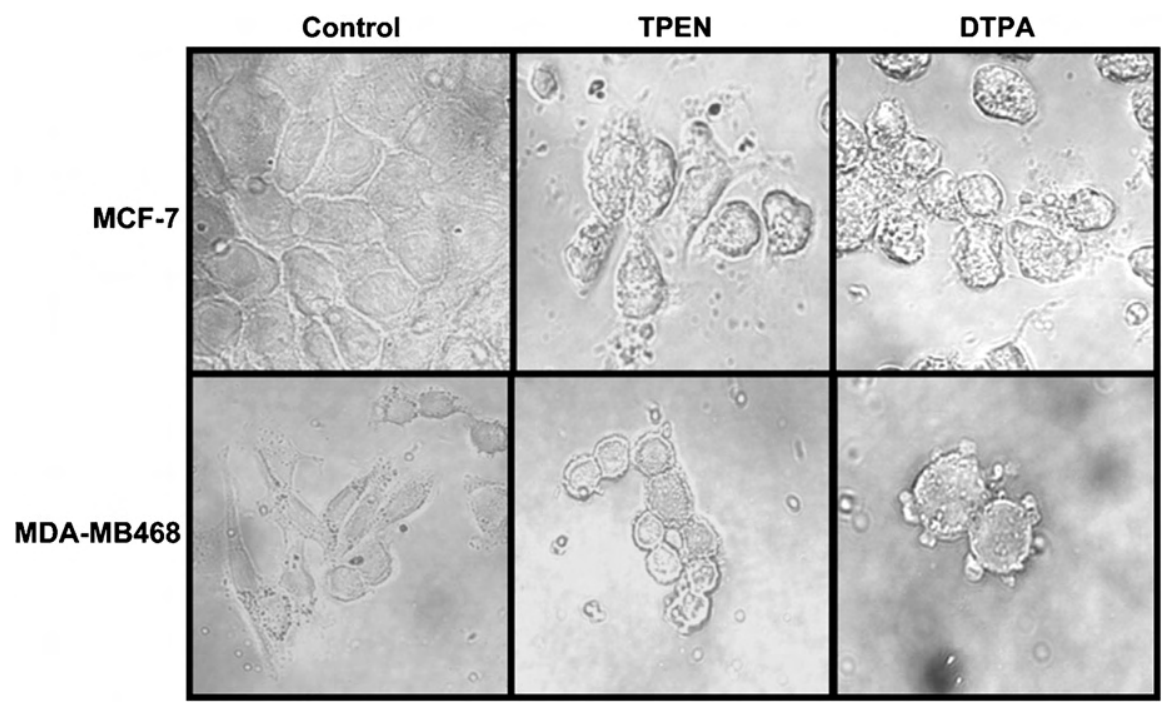

Fig. 3. Apoptotic morphology of cells treated with zinc chelators. Morphology of MCF-7 (upper: left, control; middle, TPEN (10 $\mu$ M); right, DTPA (100 $\mu$ M)) and MDA-MB468 (lower: left, control; middle: TPEN $(10 \mu \mathrm{M})$; right, DTPA $(100 \mu \mathrm{M}))$ cell lines after treatment with TPEN or DTPA for 24 and $72 \mathrm{~h}$ by inverted microscopy, respectively.

able DTPA. Thus, TPEN was already toxic at concentrations higher than $10 \mu \mathrm{M}(24 \mathrm{~h}$ treatment $), 5 \mu \mathrm{M}(48 \mathrm{~h}$ treatment), and $2.5 \mu \mathrm{M}$ after $72 \mathrm{~h}$ of treatment, respectively (Fig. 1C). The same trend could be observed for the MDA-MB468 cells. The TPENtreated MDA-MB468 showed significant cell death at concentrations higher than $5 \mu \mathrm{M}$ at $24 \mathrm{~h}$. At 48 and $72 \mathrm{~h}$ the cytotoxicity was significant at all doses tested (Fig. 1D). For cell death type confirmation, MCF-7 and MDA-MB468 cells that were treated with DTPA and TPEN have been examined using flow cytometry, by Nicoletti method, which detects apoptosistypical hypodiploid nuclei. Percentage of apoptotic cell death has been shown in Fig. 2.

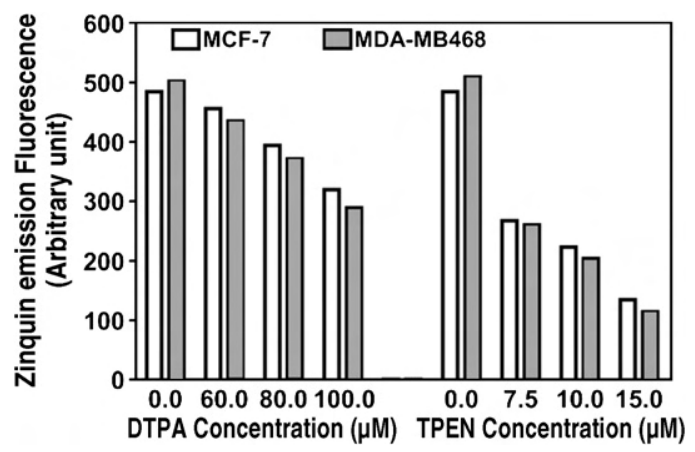

Fig. 4. The effect of DTPA (cell impermeable) and TPEN (cell permeable) zinc ion chelators on the intracellular level of zinc. The effect of DTPA (A) and TPEN (B) on intracellular zinc concentration was measure by Zinquin in the MCF-7 and MDA-MB468 breast cancer cell lines. DTPA induced significant decrease of intracellular concentration of zinc ion at $100 \mu \mathrm{M}$ in MCF-7 $(P<0.05)$ and $\geq 80 \mu \mathrm{M}$ in MDA-MB468 $(P<0.05)$. TPEN induced significant decrease of intracellular concentration of zinc ion in both MCF-7 and MDA-MB468 at all concentrations $(P<0.001)$. The presented results represent the average of four independent experiments. Standard deviation bars were omitted to preserve figure's clarity. They were not higher than $8 \%$ of total values.

\subsection{Zn chelator induced apoptotic cell morphology}

The cell morphology of treated and untreated cells was examined by phase contrast microscopy (Fig. 3). In order to confirm the nature of changes promoted by TPEN and DTPA in MCF-7 and MDA-MB468 cells, we followed several apoptosisspecific features. Chelation of endogenous labile $\mathrm{Zn}$ caused loss of cellular adherence, cell rounding and shrinkage, which was followed by moderate and rather random membrane blebbing. The apoptotic changes are more pronounced in MDA-MB468 than in MCF-7. Thus, the morphology picture corresponds well to the data obtained previously by the MTT assay.

\subsection{TPEN causes more pronounced intracellular labile zinc depletion, than DTPA}

To survey the mechanisms underlying human DTPA and TPEN-induced apoptosis, the intracellular concentration of zinc ions was detected using Zinquin emission fluorescence assay. The results confirmed that the intracellular concentration of zinc ions was decreased in both cell lines that were treated with DTPA or TPEN (Fig. 4). The cell permeable Zn chelator TPEN was, however, a more efficient $\mathrm{Zn}$-depletor in both tested cell lines. Thus, the efficacy of intracellular Zn-depletion correlates with the ability of both chelators to induce apoptosis (Fig. 2).

\subsection{The role of mitochondria in zinc depletion-induced apoptosis}

To gain more insight into the mechanism of apoptotic signalling triggered by DTPA and TPEN, we investigated the mitochondrial/apoptosome dependent apoptotic pathway. The mitochondrial pathway is mainly triggered by cell death signals that cause cellular stress (Banerji and Los, 2006; Philchenkov et al., 2004). Thus, we studied the effect of DTPA and TPEN on 

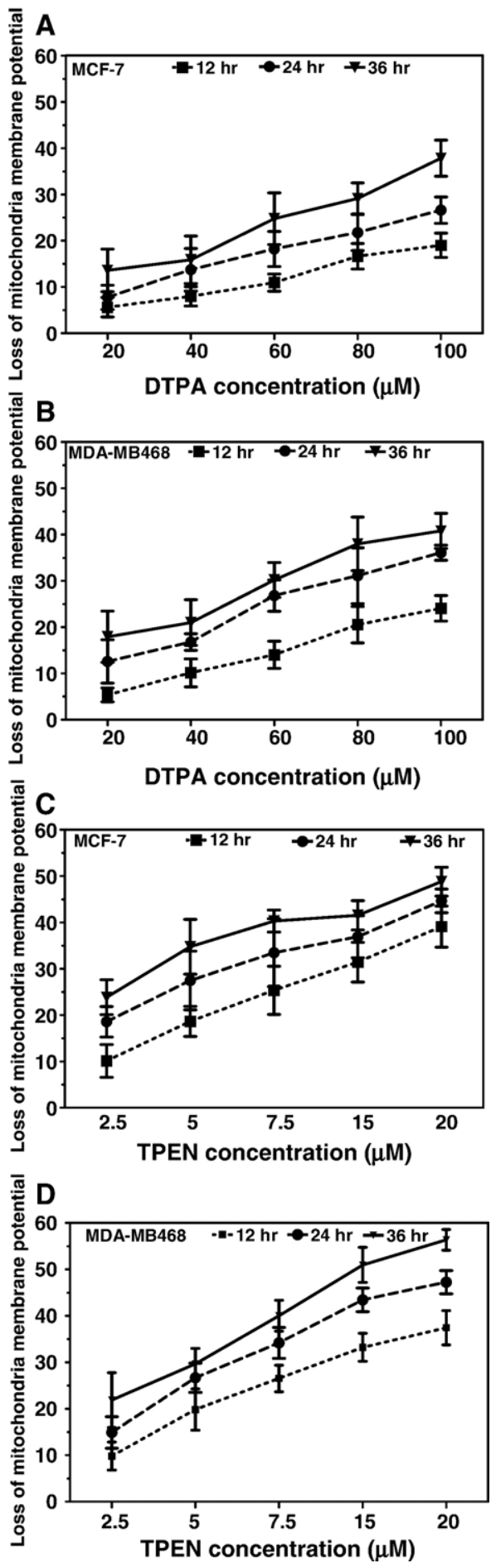

Fig. 5. The effects of DTPA and TPEN on mitochondrial membrane potential. The cells were treated with different concentration of DTPA and TPEN at different times. The loss of mitochondrial membrane potential $\left(\Psi_{\mathrm{m}}\right)$ was assessed ratiometrically by flow cytometry, using the fluorescent probe JC-1. FL-2/FL-1 ratio has been measured for control and treated cells and percent of decrease of this ratio has been indicated. DTPA induced significant decrease of mitochondrial membrane potential at concentration $\geq 60 \mu \mathrm{M}$ in MCF-7 (A) $(P<0.01)$ and MDA-MB468 (B) $(P<0.001)$ at all time tested. TPEN induced significant decrease of mitochondrial membrane potential in MCF-7 (C) at concentrations $\geq 7.5 \mu \mathrm{M}$ in 12 and $24 \mathrm{~h}$ $(P<0.01)$, while in $36 \mathrm{~h}$ significant decrease of mitochondrial membrane potential was observed at all concentrations $(P<0.001)$. In MDA-MB468 (D), TPEN induced significant decrease of mitochondrial membrane potential at all concentrations $(P<0.001)$. Results are represents the mean \pm S.D. of four independent experiments.
A

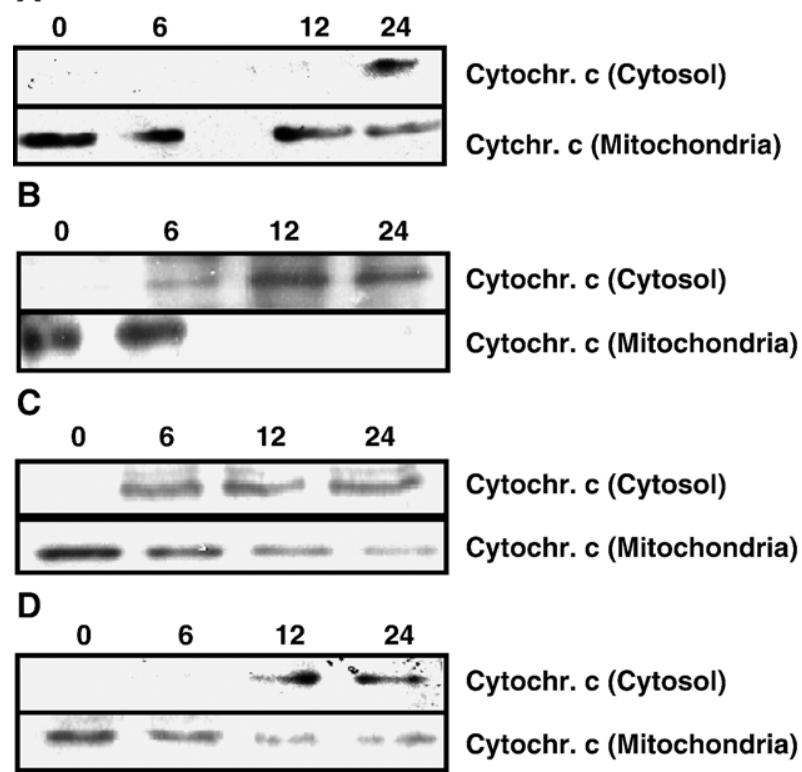

Fig. 6. DTPA and TPEN induce release of cytochrome $c$ from mitochondria Cytochrome $c$ in mitochondrial, and cytosolic (Cytosol) fractions of MCF-7 (A, C) and MDA-MB468 (B, D) cells treated with DTPA (A, B) and TPEN (C, D) were detected by Western blot.

the $\mathrm{M}$ was monitored by $\mathrm{JC}-1$; a mitochondrial dye which shows decreased fluorescence when the mitochondrial membrane potential is lost. DTPA and TPEN caused a decrease in the mitochondrial membrane potential in a time and concentration dependent manner, suggesting an impaired functioning of mitochondrial respiratory chain (Fig. 5). This experiment indicates that DTPA and TPEN triggered cell death is associated with the loss of mitochondrial membrane potential. The cell permeable $\mathrm{Zn}$-chelator TPEN was inducing $\Delta \psi \mathrm{M}$ to greater extent as compared to the cell impermeable (extracellular) $\mathrm{Zn}$ chelator DTPA.

\subsection{The mitochondrial component cytochrome $c$ is released upon DTPA and TPEN-induced cell death}

To further examine the effect of extracellular and intracellular zinc ion chelators on mitochondria, we studied the release of cytochrome $c$. Previous studies have shown that release of cytochrome $c$ from the mitochondrial intermembranous space into the cytosol is an important step in the activation of the apoptosome-dependent caspase cascade (Li et al., 1997; Slee et al., 1999). Binding of cytochrome $c$ to Apaf1 enables this protein to recruit caspase-9, thereby stimulating processing of the inactive caspase- 9 zymogen into its active form and thus triggering activation of effector caspases and nuclear fragmentation (Pan et al., 1998; Zou et al., 1997). The zinc ion chelatordependent release of cytochrome $c$ from mitochondria has previously been reported (Johnson et al., 2000; Kolenko et al., 2001; Nagano et al., 1989). To define the role of mitochondrial changes in apoptosis triggered by TPEN and DTPA we examined the kinetics of cytochrome $c$ release from 


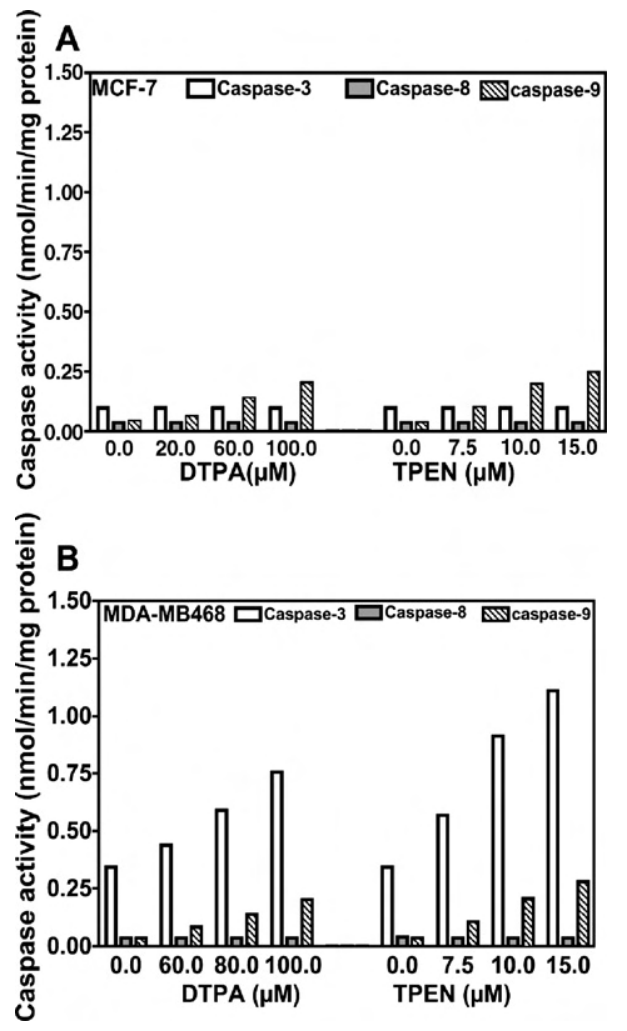

Fig. 7. Enzymatic measurement of activity of caspase family of proteases. Activity of caspase-3 (DEVDase activity), caspase-8 (IETDase activity), and caspase-9 (LEHDase activity) in MCF-7 (A) and MDA-MB468 (B) cells following treatment with DTPA and TPEN for $48 \mathrm{~h}$ was quantified by an enzymatic assay (see Materials and methods section for details). DTPA $(\geq 60 \mu \mathrm{M})$ and TPEN $(\geq 7.5 \mu \mathrm{M})$ increased significantly caspase-9 $(P<0.05)$ and caspase-3 $(P<0.001)$ activity in MDAMB468 cell line. DTPA $(\geq 80 \mu \mathrm{M})$ and TPEN $(\geq 7.5 \mu \mathrm{M})$ increased significantly caspase-9 $(P<0.05)$ activity in MCF-7 cell line. Caspase-8 activity did not show any significant increase in DTPA and TPEN treated cells $(P>0.05)$. Results are expressed as activity of the enzyme and represent the mean value for four repeats. Standard deviation bars were omitted to preserve figure's clarity. They were not higher than $4 \%$ of total values.

mitochondria and accumulation in cytosolic fraction of MCF-7 and DTPA cells treated with DTPA and TPEN by Western blotting using an anti-cytochrome $c$ antibody. As shown in Fig. 6, zinc ion chelator treatment of MCF-7 and MDA-MB468 cells caused a steady increase in cytochrome $c$ level in the cytosol that preceded induction of membrane potential change (Fig. 5) and caspase-9 activation (Fig. 7).

\subsection{The detection of caspase- $3,-8$ and -9 activation}

To explore the possible biochemical mechanisms underlying DTPA and TPEN-induced apoptosis, the activation of the caspase family of proteases was examined using colorimetric enzymatic assays. The following semi-specific substrates were used: Ac-DEVD-pNA (detects caspase-3/7), Ac-IETD-pNA (detects caspase-8), and Ac-LEHD-pNA (detects caspase-9). In MCF-7 cells the activity of caspase-9 was significantly increased upon treatment with DTPA or TPEN. MCF-7 cells however lack caspase-3 as a consequence of a 47-bp deletion within exon 3 of the pro-caspase- 3 gene that alters the reading
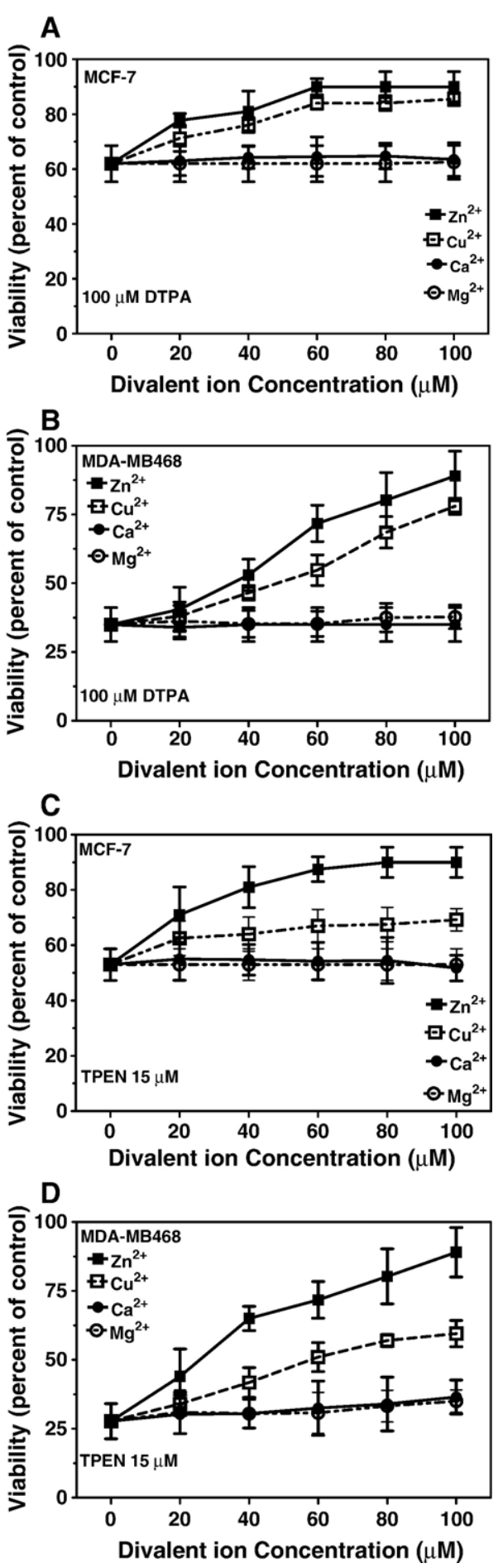

Fig. 8. The effect of divalent metal ions on the cytotoxicity of DTPA and TPEN. MCF-7 (A, C) and MDA-MB468 (B, D) breast cancer cell lines were treated for $48 \mathrm{~h}$ with the indicated zinc chelator in the presence of indicated divalent cations. The cell death was then measured by MTT assay. In MCF-7 cell line zinc $(20-100 \mu \mathrm{M})$ and copper ion $(20-100 \mu \mathrm{M})$ inhibited significantly cytotoxic effect of DTPA (A) and TPEN (C) $(P<0.01)$. In MDA-MB468 cell line zinc $(40-100 \mu \mathrm{M})$ and copper ion $(40-100 \mu \mathrm{M})$ inhibited significantly cytotoxic effect of DTPA (B) and TPEN (D) $(P<0.01)$. Results are expressed as percentage of control and represent the mean \pm S.D. of six repeats. 


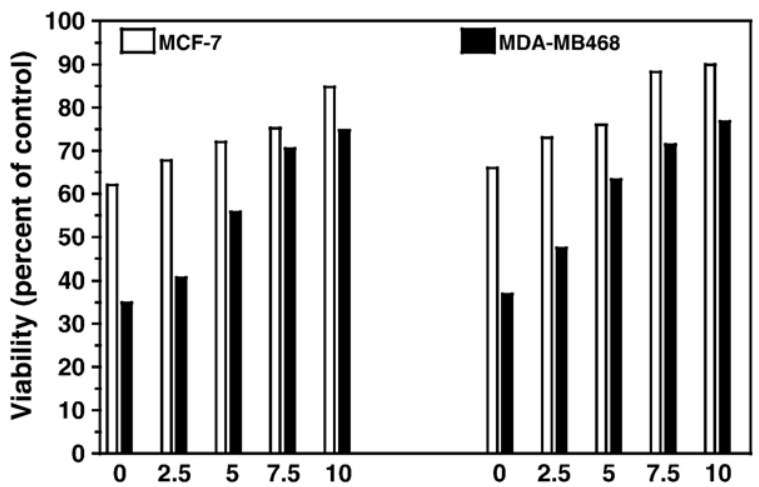

DTPA $100 \mu \mathrm{M}$ (left) and TPEN $10 \mu \mathrm{M}$ (right) in presence of $\mathrm{N}$-acetyl-L-cysteine (mM)

Fig. 9. The effect of $N$-Acetyl-L-Cysteine on the cytotoxic effect of DTPA and TPEN in the MCF-7 and MDA-MB468 human breast cancer cell lines. The cells were treated with the indicated stimuli for $48 \mathrm{~h}$. Cell death was detected by MTT assay. $N$-Acetyl-L-Cysteine $(\geq 7.5 \mathrm{mM})$ inhibited DTPA and TPEN-induced cell death in MCF-7 cells $(P<0.01)$. In MDA-MB468 cells, $N$-Acetyl-LCysteine at concentration $\geq 5 \mathrm{mM}$ significantly inhibited DTPA and TPENinduced cell death $(P<0.01)$. Results are expressed as percentage of control and represent the mean of four independent experiments. Standard deviation bars were omitted to preserve figure's clarity. They were not higher than $6 \%$ of total values.

frame of the message and results in an unstable truncated polypeptide (Kottke et al., 2002; Maddika et al., 2005). As expected, no changes in caspase-3 activity in the caspase-3negative MCF-7 cells were observed (Fig. 7A). Furthermore, we did not detect any activity of caspase-8, thus the deathreceptor-dependent pathway appears not to be involved. In MDA-MB468 however, the activities of caspase-3 and -9 were significantly increased $(P<0.05)$ upon treatment with DTPA or TPEN (Fig. 7B). Also in MDA-MB468 both Zn chelators failed to induce the activity of caspase-8. Thus, these results indicate that $\mathrm{Zn}$-depletion triggers programmed cell death via the apoptosome-dependent, mitochondrial death pathway since we observed the release of cytochrome $c$ to cytosol in the DTPA and TPEN-treated cells (Fig. 6).

\subsection{The effect of bivalent metal ions, $\mathrm{Zn}^{2+}, \mathrm{Cu}^{2+}, \mathrm{Ca}^{2+}$ and $\mathrm{Mg}^{2+}$ on the DTPA and TPEN-induced cytotoxicity}

In order to learn more about the specific role of zinc in DTPA and TPEN-induced cytotoxicity, we decided to test if other bivalent cations can counteract $\mathrm{Zn}^{2+}, \mathrm{Cu}^{2+}, \mathrm{Ca}^{2+}$ and $\mathrm{Mg}^{2+}$. Thus, MCF-7 and MDA-MB468 breast cancer cell lines were treated with DTPA $(100 \mu \mathrm{M})$ or TPEN $(15 \mu \mathrm{M})$ in the presence and absence of different concentrations of $\mathrm{Zn}^{2+}, \mathrm{Cu}^{2+}, \mathrm{Ca}^{2+}$ and $\mathrm{Mg}^{2+}$ for $48 \mathrm{~h}$. A significant increase in cell viability was observed when treated cells were co-incubated with $\mathrm{Zn}^{2+}$ or $\mathrm{Cu}^{2+}$ (Fig. 8). Under all experimental settings tested, and regardless of concentrations compared, $\mathrm{Zn}^{2+}$ supplementation more strongly counteracted the effects of DTPA or TPEN, than $\mathrm{Cu}^{2+}$ or other bivalent cations. Thus, the disruption of $\mathrm{Zn}^{2+}$-dependent biologic processes, in a biological system where $\mathrm{Cu}^{2+}$ could at least partially substitute $\mathrm{Zn}$-ions was causing DTPA- or TPENtriggered apoptosis.

\subsection{The effect of N-Acetyl-L-cysteine on TPEN- and DTPA-} induced cytotoxicity

The activation of caspase- 9 is characteristic for the classical mitochondrial, cytochrome $c$-dependent pathway. The bivalent cation supplementation experiments have shown that a chelating dependent mechanism was likely responsible for cytotoxicity. It also revealed the key role of $\mathrm{Zn}^{2+}$ and $\mathrm{Cu}^{2+}$ ions in the DTPA and TPEN-induced toxicity. Mitochondrial $\mathrm{Cu} / \mathrm{Zn}$ superoxide dismutase ( $\mathrm{Cu} / \mathrm{Zn}$ (II) SOD) is an important enzyme counteracting the damage induced by reactive oxygen species that are by-products of oxidative phosphorylation. Thus, to get further insights into the DTPA and TPEN-dependent cytotoxic pathway(s), we tested the effects of $N$-Acetyl-L-Cysteine, a broadly used clinical antioxidant, on DTPA- and TPEN-induced apoptosis. As shown in Fig. 9, pre-treatment with $N$-Acetyl-LCysteine, prevents, in a dose-dependent manner, the DTPA- and TPEN-induced cytotoxic effect in both cell lines $(P<0.05)$. Thus, this experiment indicates that the DTPA- and TPENinduced toxicity is preventable by reactive oxygen speciesscavengers.

\section{Discussion}

Zinc is a critical cofactor of many cellular metalloproteins, including transcription factors, oxidation-reduction regulators, metalloproteases, and other proteins (Moss and Bartsch, 2004; Ostrowski and Kinsner, 2001). Recent studies have shown that, besides its physiological role, zinc appears to be involved in regulation of cell proliferation and cell death. In the past decade, the existence of the cytoplasmic labile $\mathrm{Zn}$ pool has been revealed. This labile zinc pool may influence the mechanisms of cell death. Furthermore, alterations of zinc homeostasis have been reported to accompany numerous pathological conditions including cancer (Carter et al., 2002; Ho et al., 2003). Zinc depletion-induced cell death shows classical hallmarks of apoptosis (Ahn et al., 1998; Chai et al., 1999; Elmes, 1977; Jiang et al., 1995). Our results demonstrate that intracellular zinc depletion induced by DTPA and TPEN, induces apoptosis in breast cancer cell lines that occurs with the activation of caspase- 9 but not -8 . These findings, in combination with the observed mitochondrial membrane depolarization and cytochrome $c$ release from mitochondria, strongly indicate that zincdepletion-triggered apoptosis relies on the mitochondrial/ apoptosome-dependent pathway.

Our results underline the role of labile $\mathrm{Zn}$ pools in antioxidant defence and the regulation of apoptosis. These endogenous $\mathrm{Zn}$ stores may be reduced or depleted by the addition of a membrane permeable or impermeable $\mathrm{Zn}$ chelator, TPEN and DTPA. Such experimental models have also been employed previously by several researchers, including our lab (Ghavami et al., 2004; Tang et al., 2001; Truong-Tran et al., 2000b; Wang et al., 2002). Zinc is a part of the antioxidant defence system that protects cells from radicals and other oxidant species that are produced as a consequence of normal cell metabolism. Reactive oxygen species have been suggested to be involved in the initiation of apoptotic signalling. In our studies, we were able to show that the pre- 
treatment of cells with the antioxidant, $N$-Acetyl-L-Cysteine could prevent apoptosis induced by DTPA and TPEN. Prooxidant state could contribute to the molecular mechanism by which DTPA and TPEN exert their apoptotic effect. The protective role of zinc against oxidative damage is likely due to its function as a cofactor in $\mathrm{Cu} / \mathrm{Zn}$ (II) superoxide dismutase, an enzyme which removes the superoxide anion radical (TruongTran et al., 2000a). Furthermore, zinc can induce the synthesis of metallothionein, a protein that can chelate oxidation-reductionactive metals and scavenge hydroxyl radicals via its cysteine residues (Patricia et al., 2000). Thus, the role of zinc in the maintenance of the cellular oxidation-reduction state extends beyond its function as a cofactor for $\mathrm{Cu} / \mathrm{Zn}$-superoxide dismutase.

Zinc deficiency could cause oxidative damage to lipids, proteins, and DNA (Bagchi et al., 1998; Burke and Fenton, 1985; Virgili et al., 1999). In vitro studies have shown that depletion of intracellular $\mathrm{Zn}^{2+}$ by treatment of cells with TPENinduced apoptosis (Adler et al., 1999; Ahn et al., 1998; Martin et al., 1991; Tjen et al., 2002; Treves et al., 1994; Yui et al., 2002; Zalewski et al., 1993). Our results show that the membrane impermeable zinc chelator, DTPA, and membrane permeable zinc chelator, TPEN, both induced apoptosis in MCF-7 and MDA-MB-468 cells by the activation of the intrinsic/mitochondrial death pathway.

MDA-MB468 cells were significantly more sensitive towards zinc-depletion than MCF-7 cells, most likely because the latter lack the expression of caspase-3. It has been shown recently that pro-caspase- 3 is stabilised in the presence of zinc ions, either directly through binding to $\mathrm{Zn}^{2+}$ (Hyun et al., 2000; Marini et al., 2001) or indirectly through the effect of zinc on oxidation-reduction-controlled processes (Strasser et al., 2000). Thus, Zn-depletion may have a direct effect on the activation of caspase-3.

Intracellular zinc depletion causes a significant cellular stress by itself, since this bivalent cation is critical for the function of several transcription factors and enzymes. Cellular stress is known to activate the mitochondrial/apoptosome-dependent death pathway (Brouckaert et al., 2005; Ghavami et al., 2005b, 2004; Krzemieniecki et al., 2006). Moreover, mitochondria represent the cellular compartment responsible for generation of energy in the form of ATP. In addition, they may activate apoptosis by releasing cytochrome $c$ (Barczyk et al., 2005), along with other pro-apoptotic proteins, thereby activating caspase-9 and caspase-3, the major apoptosis execution enzymes (Maddika et al., 2005; Mignotte and Vayssiere, 1998). In addition, recent studies indicate that mobilization of endogenous labile $\mathrm{Zn}$ pools might interfere with normal functioning of mitochondria, and it may be responsible for activation of apoptosis (Sensi et al., 2003). Thus, consistent with the above reports, we found that chelation of intracellular labile zinc pools leads to the activation of the apoptotic cascade that is accompanied by the loss of mitochondrial transmembrane potential and caspase- 9 activation.

In summary, we show that one of the major negative effects of $\mathrm{Zn}$ ion insufficiency in the cell is the inhibition of $\mathrm{Cu} / \mathrm{Zn}$ superoxide dismutase and, in consequence, an antioxidantpreventable induction of programmed cell death. Thus, Zn- deficiency may have serious health consequences that are evoked not only directly, by the lack of $\mathrm{Zn}$ as a cofactor for metalloproteins, but also indirectly as an effect of oxidative stress within the cell. The oxidative stress may cause damage to various cellular organelles as well as DNA-strand breaks with the subsequent activation of cell death programs (Booy et al., 2005; Pour-Jafari et al., 2005). Furthermore, since "small molecules" (Hauff et al., 2005; Kroczak et al., in press; Mendoza et al., 2005) have superior pharmacokinetic features as compared to proteins and other macro-molecules, manipulation of the bioavailability of "trace metals" like zinc, that often function as cofactors, may prove to be a new promising way of pharmacologic modulation of metabolic processes.

\section{Acknowledgements}

M.L. thankfully acknowledges the support by the CFICanada Research Chair program, PCRFC-CCMF, MMSF, MHRC, and CIHR-foundation-financed programs. E.P.B. thankfully acknowledges the support by the CIHR. The salary of S.G. has been supported by the MHRC and CCMF.

\section{References}

Adler, M., Shafer, H., Hamilton, T., Petrali, J.P., 1999. Cytotoxic actions of the heavy metal chelator TPEN on NG108-15 neuroblastoma-glioma cells. Neurotoxicology 20, 571-582.

Ahn, Y.H., Kim, Y.H., Hong, S.H., Koh, J.Y., 1998. Depletion of intracellular zinc induces protein synthesis-dependent neuronal apoptosis in mouse cortical culture. Exp. Neurol. 154, 47-56.

Bagchi, D., Vuchetich, P.J., Bagchi, M., Tran, M.X., Krohn, R.L., Ray, S.D., Stohs, S.J., 1998. Protective effects of zinc salts on DTPA-induced hepatic and brain lipid peroxidation, glutathione depletion, DNA damage and peritoneal macrophage activation in mice. Gen. Pharmacol. 30, 43-50.

Banerji, S., Los, M., 2006. Important differences between topoisomerase-I and II targeting agents. Cancer Biol. Ther. 5, 965-966.

Barczyk, K., Kreuter, M., Pryjma, J., Booy, E.P., Maddika, S., Ghavami, S., Berdel, W.E., Roth, J., Los, M., 2005. Serum cytochrome $c$ indicates in vivo-apoptosis and it can serve as a prognostic marker during cancer therapy. Int. J. Cancer. 114, 167-173.

Behroozi, S.J., Kim, W., Dannaldson, J., Gates, K.S., 1996. 1,2-dithiolan-3-one 1-oxides: a class of thiol-activated DNA-cleaving agents that are structurally related to the natural product leinamycin. Biochemistry 35, 1768-1774.

Berg, J.M., Shi, Y., 1996. The galvanization of biology: a growing apprecia-tion for the roles of zinc. Science 271, 1081-1085.

Bergan, T., Klaveness, J., Aasen, A.J., 2001. Chelating agents. Chemotherapy 47, 10-14.

Booy, E.P., Kadkhoda, K., Johar, D., Bay, G.H., Los, M., 2005. The immune system, involvement in neurodegenerative diseases, ageing and cancer. Curr. Med. Chem. Anti-Inflamm. Anti-Allerg. Agents 4, 349-353.

Bradford, M.M., 1976. A rapid and sensitive method for the quantities of microgram of protein utilizing the principle of protein-dye binding. Anal. Biochem. 72, 248-254.

Brouckaert, G., Kalai, M., Saelens, X., Vandenabeele, P., 2005. Apoptotic pathways and their regulation. In: Los, M., Gibson, S.B. (Eds.), Apoptotic Pathways as Target for Novel Therapies in Cancer and Other Diseases. Springer Academic Press, New York.

Burke, J.P., Fenton, M.R., 1985. Effect of a zinc-deficient diet on lipid peroxidation in liver and tumor subcellular membranes. Proc. Soc. Exp. Biol. Med. 179, 187-191.

Carter, J.E., Truong-Tran, A.Q., Grosser, D., Ho, L., Ruffin, R.E., Zalewski, P.D., 2002. Involvement of redox events in caspase activation in zinc-depleted airway epithelial cells. Biochem. Biophys. Res. Commun. 297, 1062-1070. 
Chai, F., Truong-Tran, A.Q., Ho, L.H., Zalewski, P.D., 1999. Regulation of caspase activation and apoptosis by cellular zinc fluxes and zinc deprivation: a review. Immunol. Cell Biol. 77, 272-278.

Elmes, M.E., 1977. Apoptosis in the small intestine of zinc-deficient and fasted rats. J. Pathol. 123, 219-223.

Fukamachi, Y., Karasaki, Y., Sugiura, T., Itoh, H., Abe, T., Yamamura, K., Higashi, K., 1998. Zinc suppresses apoptosis of U937 cells induced by hydrogen peroxide through an increase of the Bcl-2/Bax ratio. Biochem. Biophys. Res. Commun. 246, 364-369.

Ghavami, S., Kerkhoff, C., Los, M., Hashemi, M., Sorg, C., Karami-Tehrani, F., 2004. Mechanism of apoptosis induced by S100A8/A9 in colon cancer cell lines: the role of ROS and the effect of metal ions. J. Leukoc. Biol. 76, $169-175$.

Ghavami, S., Barczyk, K., Maddika, S., Vogl, T., Steinmüller, L., Pour-Jafari, H., Evans, J.A., Los, M., 2005a. Monitoring of programmed cell death in vivo and in vitro, - new and old methods of cancer therapy assessment. In: Los, M., Gibson, S.B. (Eds.), Apoptotic Pathways as Target for Novel Therapies in Cancer and Other Diseases. Springer Science+Business Media, Inc., New York, pp. 323-341.

Ghavami, S., Hashemi, M., Kadkhoda, K., Alavian, S.M., Bay, G.H., Los, M., 2005b. Apoptosis in liver diseases - detection and therapeutic applications. Med. Sci. Monit. 11, RA337-RA345.

Hashemi, M., Kroczak, T.J., 2005. Apoptosis and autoimmune disease. Curr. Med. Chem. Anti-Inflamm. Anti-Allerg. Agents 4, 429-437.

Hashemi, M., Karami-Tehrani, F., Ghavami, S., Maddika, S., Los, M., 2005. Adenosine and deoxyadenosine induces apoptosis in oestrogen receptorpositive and negative human breast cancer cells via the intrinsic pathway. Cell Prolif. 38, 269-285.

Hauff, K., Zamzow, C., Law, W.J., de Melo, J., Kennedy, K., Los, M., 2005. Peptide-based approaches to treat asthma, arthritis, other autoimmune diseases and pathologies of the central nervous system. Arch. Immunol. Ther. Exp. 53, 308-320.

Heximer, S.P., Forsdyke, D.R., 1993. A human putative lymphocyte G0/ G1switch gene homologous to a rodent gene encoding a zinc-binding potential transcription factor. DNA Cell Biol. 12, 73-88.

Ho, E., Courtemanche, C., Ames, B.N., 2003. Zinc deficiency induces oxidative DNA damage and increases p53 expression in human lung fibroblasts. J. Nutr. 133, 2543-2548.

Huang, E.P., 1997. Metal ions and synaptic transmission: think zinc. Proc. Natl. Acad. Sci. U. S. A. 94, 13386-13387.

Hyun, H.J., Sohn, J., Ahn, Y.H., Shin, H.C., Koh, J.Y., Yoon, Y.H., 2000. Depletion of intracellular zinc induces macromolecule synthesis and caspase-dependent apoptosis of cultured retinal cells. Brain Res. 869, $39-48$.

Jiang, S., Chow, S.C., McCabe, J.M.J., Orrenius, S., 1995. Lack of $\mathrm{Ca}^{2+}$ involvement in thymocyte apoptosis induced by chelation of intracellular $\mathrm{Zn}^{2+}$. Lab. Invest. 73, 111-117.

Johnson, V.L., Ko, S.C., Holmstrom, T.H., Eriksson, J.E., Chow, S.C., 2000. Effector caspases are dispensable for the early nuclear morphological changes during chemical-induced apoptosis. J. Cell Sci. 113 (Pt 17), 2941-2953.

Kennedy, C.J., Rakoczy, P.E., Robertson, T.A., Papadimitriou, J.M., Constable, I.J., 1994. Kinetic studies on phagocytosis and lysosomal digestion of rod outer segments by human retinal pigment epithelial cells in vitro. Exp. Cell Res. 210, 209-214.

Klug, A., 1999. Zinc finger peptides for the regulation of gene expression. J. Mol. Biol. 293, 215-218.

Kolenko, V.M., Uzzo, R.G., Dulin, N., Hauzman, E., Bukowski, R., Finke, J.H., 2001. Mechanism of apoptosis induced by zinc deficiency in peripheral blood T lymphocytes. Apoptosis 6, 419-429.

Kottke, T.J., Blajeski, A.L., Meng, X.W., Svingen, P.A., Ruchaud, S., Mesner, P.W., Boerner, S.A.J., Samejima, K., Henriquez, V., Chilcote, T.J., Lord, J., Salmon, M., Earnshaw, W.C., Kaufmann, S.H., 2002. Lack of correlation between caspase activation and caspase activity assays in paclitaxeltreated MCF-7 breast cancer cells. J. Biol. Chem. 277, 804-815.

Kroczak, T.J., Baran, J., Pryjma, J.S.,M., Rashedi, I., Hernandez, E., Alberti, E.M.,S., Los, M., 2006. The emerging importance of DNA mapping and other comprehensive screening techniques as tools to identify new drug targets and as a mean of (cancer) therapy personalization. Expert Opin. Ther. Targets 10 (2), 289-302.

Krzemieniecki, K., Szpyt, E., Rashedi, I., Gawron, K., Los, M., 2006. Targeting of solid tumors and blood malignancies by antibody-based therapies EGFR-pathway as an example. Centr. Eur. J. Biol. 1, 167-182.

Li, P., Nijhawan, D., Budihardjo, I., Srinivasula, S.M., Ahmad, M., Alnemri, E.S., Wang, X., 1997. Cytochrome $c$ and dATP-dependent formation of Apaf-1/ caspase-9 complex initiates an apoptotic protease cascade. Cell 91, 479-489.

Los, M., Herr, I., Friesen, C., Fulda, S., Schulze-Osthoff, K., Debatin, K.M., 1997. Cross-resistance of CD95-and drug-induced apoptosis as a consequence of deficient activation of caspases (ICE/Ced-3 proteases). Blood 90 , 3118-3129.

Los, M., Wesselborg, S., Schulze-Osthoff, K., 1999. The role of caspases in development, immunity, and apoptotic signal transduction: lessons from knockout mice. Immunity 10, 629-639.

Maddika, S., Booy, E.P., Johar, D., Gibson, S.B., Ghavami, S., Los, M., 2005. Cancer-specific toxicity of apoptin is independent of death receptors but involves the loss of mitochondrial membrane potential and the release of mitochondrial cell death mediators by a Nur77-dependent pathway. J. Cell Sci. 118, 4485-4493.

Mares-Perlman, J.A., Klein, R., Klein, B.E., Greger, J.L., Brady, W.E., Palta, M., Ritter, L.L., 1996. Association of zinc and antioxidant nutrients with age-related maculopathy. Arch. Ophthalmol. 114, 991-997.

Marini, M., Frabetti, F., Canaider, S., Dini, L., Falcieri, E., Poirier, G.G., 2001 Modulation of caspase- 3 activity by zinc ions and by the cell redox state. Exp. Cell Res. 266, 323-332.

Martin, S.J., Mazdai, G., Strain, J.J., Cotter, T.G., Hannigan, B.M., 1991 Programmed cell death (apoptosis) in lymphoid and myeloid cell lines during zinc deficiency. Clin. Exp. Immunol. 83, 338-343.

McCabe Jr., M.J., Jiang, S.A., Orrenius, S., 1993. Chelation of intracellular zinc triggers apoptosis in mature thymocytes. Lab. Invest. 69, 101-110.

McClain, C.J., Kasarskis Jr., E.J., Allen, J.J., 1985. Functional consequences of zinc deficiency. Prog. Food Nutr. Sci. 9, 185-226.

Mendoza, F.J., Espino, P., Cann, C.L., Bristow, N., McCrea, K., Los, M., 2005. Anti-tumor chemotherapy utilizing peptide-based approaches - apoptotic pathways, kinases and proteasome as targets. Arch. Immunol. Ther. Exp. 53, $47-60$.

Mignotte, B., Vayssiere, J.L., 1998. Mitochondria and apoptosis. Eur. J. Biochem. $252,1-15$.

Moss, M.L., Bartsch, J.W., 2004. Therapeutic benefits from targeting of ADAM family members. Biochemistry 43, 7227-7235.

Nagano, T., Hirano, T., Hirobe, M., 1989. Superoxide dismutase mimics based on iron in vivo. J. Biol. Chem. 264, 9243-9249.

Ostrowski, K., Kinsner, A., 2001. Inhibition of angiogenesis in the treatment of tumors. Arch. Immunol. Ther. Exp. 49, 27-31.

Pan, G., Humke, E.W., Dixit, V.M., 1998. Activation of caspases triggered by cytochrome $c$ in vitro. FEBS Lett. 426, 151-154.

Patricia, I.O., Michael, S., Paola, C.Z., Carl, L.K., 2000. Zinc deficiency induces oxidative stress and AP-1 activation in 3 T3 cells. Free Radic. Biol. Med. 28, 1091-1099.

Perry, D.K., Smyth, M.J., Stennicke, H.R., Salvesen, G.S., Duriez, P., Poirier, G.G., Hannun, Y.A., 1997. Zinc is a potent inhibitor of the apoptotic protease, caspase-3. A novel target for zinc in the inhibition of apoptosis. J. Biol. Chem. $272,18530-18533$.

Philchenkov, A., Zavelevich, M., Kroczak, T.J., Los, M., 2004. Caspases and cancer: mechanisms of inactivation and new treatment modalities. Exp. Oncol. 26, 82-97.

Pour-Jafari, H., Ghavami, S., Maddika, S., 2005. Mitochondrial physiology and toxicity (mitotoxicity); importance for cancer, programmed cell death and the immune system. Curr. Med. Chem. Anti-Inflamm. Anti-Allerg. Agents 4, 439-451.

Prasad, A.S., 1985. Laboratory diagnosis of zinc deficiency. J. Am. Coll. Nutr. 4, 591-598.

Prasad, A.S., 1991. Discovery of human zinc deficiency and studies in an experimental human model. Am. J. Clin. Nutr. 53, 403-412.

Rudolf, E., Cervinka, M., 2004. Depletion of endogenous zinc stores induces oxidative stress and cell death in human melanoma cells. Acta Medica (Hradec Kralove) 47, 91-96. 
Sensi, S.L., Ton-That, D., Sullivan, P.G., Jonas, E.A., Gee, K.R., Kaczmarek, L.K., Weiss, J.H., 2003. Modulation of mitochondrial function by endogenous $\mathrm{Zn}^{2+}$ pools. Proc. Natl. Acad. Sci. U. S. A. 100, 6157-6162.

Slee, E.A., Harte, M.T., Kluck, R.M., Wolf, B.B., Casiano, C.A., Newmeyer, D.D., Wang, H.G., Reed, J.C., Nicholson, D.W., Alnemri, E.S., Green, D.R., Martin, S.J., 1999. Ordering the cytochrome $c$-initiated caspase cascade: hierarchical activation of caspases-2, 3, 6, 7, 8, and 10 in a caspase-9-dependent manner. J. Cell Biol. 144, 281-292.

Strasser, A., O’Connor, L., Dixit, V.M., 2000. Apoptosis signaling. Annu. Rev. Biochem. 69, 217-245.

Sukegawa, J., Blobel, G., 1993. A nuclear pore complex protein that contains zinc finger motifs, binds DNA, and faces the nucleoplasm. Cell 72, 29-38.

Tang, Z.L., Wasserloos, K., St Croix, C.M., Pitt, B.R., 2001. Role of zinc in pulmonary endothelial cell response to oxidative stress. Am. J. Physiol., Lung Cell. Mol. Physiol. 281, L243-L249.

Tjen, W.W., Haase, H., Biagioli, Beyersmann, M.D., 2002. Induction of apoptosis in mammalian cells by cadmium and zinc. Environ. Health Perspect. 110, 865-867.

Treves, S., Trentini, P.L., Ascanelli, M., Bucci, G., Di Virgilio, F., 1994. Apoptosis is dependent on intracellular zinc and independent of intracellular calcium in lymphocytes. Exp. Cell Res. 211, 339-343.

Truong-Tran, A.Q., Ho, L.H., Chai, F., Zalewski, P.D., 2000a. Cellular zinc fluxes and the regulation of apoptosis/gene-directed cell death. J. Nutr. 130, 1459S-1466S
Truong-Tran, A.Q., Ruffin, R.E., Zalewski, P.D., 2000b. Visualization of labile zinc and its role in apoptosis of primary airway epithelial cells and cell lines. Am. J. Physiol., Lung Cell. Mol. Physiol. 279, L1172-L1183.

Vallee, B.L., Falchuk, K.H., 1993. The biochemical basis of zinc physiology. Physiol. Rev. 73, 79-118.

Virgili, F., Canali, R., Figus, E., Vignolini, F., Nobili, F., Mengheri, E., 1999. Intestinal damage induced by zinc deficiency is associated with enhanced $\mathrm{Cu} / \mathrm{Zn}$ (II) superoxide dismutase activity in rats: effect of dexamethasone or thyroxine treatment. Free Radic. Biol. Med. 26, 1194-1201.

Wang, X., Fosmire, G.J., Gay, C.V., Leach Jr., R.M., 2002. Short-term zinc deficiency inhibits chondrocyte proliferation and induces cell apoptosis in the epiphyseal growth plate of young chickens. J. Nutr. 132, 665-673.

Yui, S., Nakatani, Y., Hunter, M.J., Chazin, W.J., Yamazaki, M., 2002. Implication of extracellular zinc exclusion by recombinant human calprotectin (MRP8 and MRP14) from target cells in its apoptosis-inducing activity. Mediat. Inflamm. 11, 165-172.

Zalewski, P.D., Forbes, I.J., Betts, W.H., 1993. Correlation of apoptosis with change in intracellular labile $\mathrm{Zn}$ (II) using zinquin [(2-methyl-8-p-toluenesulphonamido-6-quinolyloxy)acetic acid], a new specific fluorescent probe for Zn(II). Biochem. J. 296 (Pt 2), 403-408.

Zou, H., Henzel, W.J., Liu, X., Lutschg, A., Wang, X., 1997. Apaf-1, a human protein homologous to $C$. elegans CED-4, participates in cytochrome $c$ dependent activation of caspase-3. Cell 90, 405-413. 